\title{
Pengaruh Perbandingan Puree Wortel (Daucus carota L.) Dan Terigu Terhadap Karakteristik Roti Tawar
}

\author{
Effects Comparison of Carrot Puree (Daucus carota L.) and Wheat Flour Against the \\ Characteristics of Bread
}

Norma Yunita*, I Made Sugitha, I Gusti Ayu Ekawati

Program Studi Ilmu dan Teknologi Pangan, Fakultas Teknologi Pertanian, Universitas Udayana, Jl. Raya Kampus Unud, Jimbaran, Kuta Selatan, Badung-Bali

*Korespondensi penulis: Norma Yunita, Email: Nurmayu4@gmail.coms

\begin{abstract}
This research was conducted with the to determine the comparative effect of carrot puree and wheat flour on the characteristic of bread and to know of the exact comparison of carrot puree and wheat flour to obtain the best characteristic of bread. The experimental design used was a Randomized Block Design (RBD) with treatment factor ratio of carrot puree and wheat flour that was 0\%: 100\%, 10\%: 90\%, 20\%: 80\%, 30\%: 70\%, 40\%: 60\%, and 50\%: 50\%. The treatment was repeated 3 times to obtain 18 experimental units. Data were analyzed with the Anova test and if the treatment had an effect on the variables then proceeded with the Duncan test. The results showed that the comparison of carrot puree and wheat flour affected the water content, ash content, swelling power, total carotene, color, aroma, texture, taste, pore uniformity, and overall acceptance. Comparison of $30 \%$ carrot puree: $70 \%$ wheat flour produced the best characteristics of bread with the criteria water content of $16.13 \%$, ash content of $1.37 \%$, loaf volume of $123.65 \%$ and total carotene content of $13.01 \mathrm{mg} / 100 \mathrm{~g}$. Orange color, slightly carrot aroma, soft texture, pore uniformity (uniform) liked and overall acceptance of bread very liked.
\end{abstract}

Keywoards : Bread, wheat flour, carrot puree

\section{PENDAHULUAN}

Roti tawar merupakan adonan roti yang terbuat dari terigu dengan peragian atau adonan tanpa menggunakan telur dengan sedikit gula atau tidak sama sekali. Penggunaan gula pada pembuatan roti tawar berfungsi sebagai sumber energi bagi ragi saat fermentasi (Heruhidyat, 2009). Fermentasi adalah proses pemecahan senyawa-senyawa organik melalui bantuan aktivitas mikroba. Mikroba yang berperan dalam fermentasi roti yaitu khamir atau ragi roti. Khamir yang berperan dalam proses ini adalah Sacharomyces cerevisae. Roti tawar banyak dikonsumsi oleh masyarakat luas. Harga yang relatif murah, menyebabkan roti tawar mudah dijangkau oleh seluruh lapisan masyarakat. Namun, untuk meningkatkan kandungan gizi yang lain pada roti tawar perlu adanya diversifikasi pangan dan berfungsi sebagai pangan fungsional yaitu dengan menambahkan wortel.

Wortel merupakan tanaman yang dikenal memiliki kandungan pro-vitamin A yang sangat tinggi, mudah didapatkan dan manfaatnya sangat banyak bagi kesehatan tubuh. Tanaman ini salah satunya dapat dimanfaatkan untuk mengatasi masalah penurunan serta pencegahan permasalahan gizi mikro yaitu KVA (Kurang vitamin A) karena memiliki kandungan pro- 
vitamin A yaitu $\beta$-karoten yang tinggi (Mehrir, 2012). Selain kaya akan pro-vitamin A wortel juga kaya akan sumber vitamin $\mathrm{C}$, vitamin $\mathrm{K}$, serat, dan potassium. Berdasarkan penelitian Mulyani et al.,(2013) roti manis yang ditambahkan tepung wortel $10 \%$ menghasilkan kandungan $\beta$-karoten 3,58 mg/100g. Pembuatan roti tawar dengan perbandingan wortel ini menggunakan wortel janis chantenay dalam bentuk puree wortel. Puree wortel merupakan salah satu olahan wortel yang kenampakannya seperti bubur. Penambahan puree wortel akan menghasilkan karakteristik roti tawar dengan warna yang khas. Warna oranye yang dihasilkan oleh wortel akan menambah daya tarik masyarakat terhadap roti tawar. Pembuatan roti tawar dengan perbandingan puree wortel dan terigu diharapkan dapat menambah variasi roti tawar dan dapat menambah nilai gizi yang lebih untuk kesehatan.

\section{METODE PENELITIAN}

\section{Tempat dan Waktu Penelitian}

Penelitian ini dilakukan di Laboratorium Pengolahan Pangan, Laboratorium Analisis Pangan Fakultas Teknologi Pertanian Universitas Udayana, Jl. PB. Sudirman, Denpasar dan Laboratorium rekayasa mutu dan proses dijalan Bukit Jimbaran. Penelitian dilaksanakan dari bulan September - Oktober 2018.

\section{Bahan dan Alat}

Bahan-bahan yang digunakan dalam melaksanakan penelitian ini terdiri dari bahan baku, bahan tambahan, dan bahan kimia. Bahan baku terdiri dari wortel jenis chantenay, terigu merk cakra kembar, ragi (Fermipan), air, gula, garam, susu bubuk, shortening, dan bread improver (Beaker's Bonus).

Bahan untuk analisis kimia meliputi aquades, petrolium benzena, aseton, $\mathrm{Na}_{2} \mathrm{SO}_{4}$. Alat-alat yang digunakan dalam proses pengolahan yang terdiri dari kompor gas, panci, pisau, talenan, waskom, panci, kukusan, sendok, timbangan digital dan alat yang digunakan untuk analisis sifat fisik dan kimia adalah lumpang, desikator, cawan porselin, oven (Memmert), timbangan analitik (Shimadzu), pinset, muffle (Daihan), gelas beaker (Pyrex), gelas ukur (Pyrex), destilator, biuret (Pyrex), pipet volume (Pyrex), pompa karet, labu takar (Pyrex), , kertas saring, labu pemisah, labu takar $5 \mathrm{ml}$, perangkat computer dan seperangkat alat untuk evaluasi sensoris.

\section{Rancangan Penelitian}

Rancangan penelitian yang digunakan adalah Rancangan Acak Kelompok (RAK) dengan perlakuan perbandingan puree wortel dan terigu yaitu:

$\mathrm{P} 0=0 \%: 100 \%$

$\mathrm{P} 1=10 \%: 90 \%$

$\mathrm{P} 2=20 \%: 80 \%$

$\mathrm{P} 3=30 \%: 70 \%$

$\mathrm{P} 4=40 \%: 60 \%$

$\mathrm{P} 5=50 \%: 50 \%$

Masing-masing perlakuan dilakukan pengulangan sebanyak 3 kali sehingga diperoleh 18 unit percobaan. Data yang diperoleh dari hasil penelitian dianalisis dengan SPSS dan apabila perlakuan berpengaruh terhadap variabel maka 
dilanjutkan dengan uji Duncan multipe range test

(Gomez dan Gomez, 1995).

\section{Pelaksanaan Penelitian}

Persiapan bahan yang digunakan dalam pembuatan roti tawar yaitu, terigu, puree wortel, shortening, gula pasir, garam, air, beaker's bonus, dan susu bubuk. Bahan yang digunakan kemudian ditimbang sesuai dengan formula. Formula Roti tawar perbandingan puree wortel dan terigu dapat dilihat pada Tabel 1.

Tabel 1. Formula adonan roti tawar dengan perbandingan terigu dan puree wortel

\begin{tabular}{clcccccc}
\hline \multirow{2}{*}{ No } & \multicolumn{1}{c}{ Bahan } & P0 & P1 & P2 & P3 & P4 & P5 \\
\cline { 2 - 7 } & & 0 & 10 & 20 & 30 & 40 & 50 \\
\hline 1 & Puree wortel (\%) & 100 & 90 & 80 & 70 & 60 & 50 \\
2 & Terigu (\%) & 8 & 8 & 8 & 8 & 8 & 8 \\
3 & Shortening (\%) & 2 & 2 & 2 & 2 & 2 & 2 \\
4 & Garam (\%) & 4,8 & 4,8 & 4,8 & 4,8 & 4,8 & 4,8 \\
5 & gula pasir (\%) & 62 & 62 & 62 & 62 & 62 & 62 \\
6 & Air (\%) & 0,8 & 0,8 & 0,8 & 0,8 & 0,8 & 0,8 \\
7 & Bread improver (\%) & 8 & 8 & 8 & 8 & 8 & 8 \\
8 & Susu bubuk (\%) & 3,6 & 3,6 & 3,6 & 3,6 & 3,6 & 3,6 \\
9 & Ragi (\%) & & & & & & \\
\hline
\end{tabular}

Sumber: Sudarno (2015), yang dimodifikasi

Keterangan: \% bahan berdasarkan jumlah terigu dengan puree wortel

\section{Pelaksanaan penelitian terdiri dari 2 tahap :}

\section{Tahap I. Pembuatan puree wortel}

Menurut Bima (2014), proses pembuatan puree wortel dimulai dari kulit wortel dikupas untuk memisahkan bagian kulit wortel dan bagian wortel yang busuk. Setelah itu, wortel dicuci bersih dengan air mengalir. Ditimbang 500 gram dan dipotong dengan ukuran $2 \times 2 \mathrm{~cm}$ untuk memudahkan proses blanching. Wortel di steam blancing dengan suhu $75{ }^{\circ} \mathrm{C}$ selama 2 menit. Setelah itu, wortel dihaluskan dengan blender sampai menjadi puree wortel.

\section{Tahap II. Proses pembuatan roti tawar dengan}

\section{penambahan puree wortel}

Pembuatan roti tawar menurut Sudarno (2015), yaitu Langkah pertama, dicampur terigu sesuai perlakuan, 4,8\% gula pasir, 3,6\% yeast instan, $8 \%$ susu bubuk, $0,8 \%$ bread improver, dan $62 \%$ air hingga adonan homogen. Ditambahkan puree wortel sesuai perlakuan dan adonan diuleni. Kemudian ditambahkan shortening, garam dan diuleni kembali hingga kalis. Adonan yang sudah kalis kemudian ditimbang dan dibulatkan. Selanjutnya adonan difermentasi I selama 15 menit pada suhu ruang. Pada fermentasi pertama ini terjadi pemecahan gula (karbohidrat) menjadi $\mathrm{CO}_{2}$ dan alkohol. Kemudian, adonan dikempiskan, dibentuk dan diletakkan dalam loyang dan ditutup dengan kain, dilakukan fermentasi II selama 20 menit pada suhu ruang. Fermentasi kedua bertujuan untuk untuk memperbaiki tekstur serta untuk mencapai bentuk yang baik. Setelah adonan mengembang, adonan dimasukkan ke dalam oven dengan suhu $200^{\circ} \mathrm{C}$ selama 25 menit. 


\section{HASIL DAN PEMBAHASAN}

\section{Karakteristik Bahan Baku}

Berdasarkan hasil analisis bahan baku diperoleh kandungan pada terigu : air (5,86\%), abu (0,44\%), Kandungan pada puree wortel : air $(39,90 \%)$, abu
$(0,16 \%)$, dan total karoten $(12,302 \mathrm{mg} / 100 \mathrm{~g})$. Data yang diperoleh pada analisis bahan baku akan digunakan sebagai data penunjang pada pembahasan hasil analisis. Hasil analisis kadar air, kadar abu, total karoten dari terigu dan puree wortel dapat dilihat pada Tabel 2.

Tabel 2. Hasil analisis kadar air, kadar abu, total karoten dari terigu dan puree wortel

\begin{tabular}{lccc}
\hline Bahan & Kadar Air $(\%)$ & Kadar Abu $(\%)$ & Total Karoten $(\%)$ \\
\hline Terigu & 5,86 & 0,44 & - \\
Puree wortel & 39,90 & 0,16 & 12,30 \\
\hline
\end{tabular}

\section{Kadar Air}

Hasil sidik ragam menunjukkan bahwa perbandingan puree dengan terigu berpengaruh sangat nyata $(\mathrm{P}<0,01)$ terhadap kadar air roti tawar. Tabel 3 menunjukkan kadar air roti tawar berkisar antara 13,81\%sampai dengan 19,00\%. Kadar air roti tawar tertinggi diperoleh dari perlakuan P5(50\% puree wortel : 50\% terigu). Peningkatan kadar air terjadi seiring dengan meningkatnya penambahan puree wortel. Nilai kadar air roti tawar berdasarkan SNI roti tawar maksimal adalah 40\% (Anon., 1995).

\section{Kadar Abu}

Hasil sidik ragam menunjukkan bahwa perbandingan puree wortel dan terigu berpengaruh nyata $(\mathrm{P}<0,05)$ terhadap kadar abu roti tawar). Tabel 3 menunjukkan kadar abu roti tawar dengan penmbahan puree wortel berkisar antara $1,20 \%$ sampai $1,83 \%$. Kadar abu tertinggi roti tawar dengan penambahan puree wortel diperoleh dari perlakuan P0 yaitu 1,83\% , sedangkan kadar abu terendah diperoleh dari perlakuan P5 yaitu 1,20\%. Penurunan kadar abu terjadi seiring dengan meningkatnya penambahan puree wortel, hal ini didukung oleh hasil analisis kadar abu bahan baku pada puree wortel lebih rendah yaitu $0,16 \%$ dibanding dengan terigu yaitu $0,44 \%$.

\section{Daya Kembang}

Hasil sidik ragam menunjukkan bahwa perbandingan puree wortel dan terigu berpengaruh nyata $(\mathrm{P}<0,05)$ terhadap daya kembang roti tawar. Tabel 3 menunjukkan daya kembang roti tawar dengan perbandingan puree wortel dan terigu berkisar antara 102,39\% sampai 136,38\%. Daya kembang tertinggi roti tawar dengan perbandingan puree wortel dan terigu diperoleh pada perlakuan P0 yaitu 136,38\%, sedangkan daya kembang terendah roti tawar diperoleh pada perlakuan P5 yaitu 102,39\%.

Terigu mengandung protein yang disebut gluten sedangkan puree wortel tidak mengandung gluten. Gluten memiliki kandungan protein yang membentuk massa lengket dan elastis ketika dicampur dengan air. Gluten mengandung dua 
jenis protein yaitu glutenin dan gliadin. Glutenin memberikan sifat-sifat yang tegar pada adonan dan gliadin memberikan sifat yang elastis dan mengembang sehingga mampu menahan gas yang terbentuk selama proses fermentasi adonan
(Koswara,2009). Daya kembang roti tawar dengan perbandingan puree wortel dan terigu mengalami penurunan daya kembang. Menurunnya daya kembang roti tawar disebkan karena berkurangnya terigu yang ditambahkan pada setiap perlakuan.

Tabel 3. Hasil analisis kadar air, kadar abu, daya kembang dan total karoten pada roti tawar dengan perbandingan puree wortel

\begin{tabular}{ccccc}
\hline Perlakuan & $\begin{array}{c}\text { Kadar Air } \\
(\%)\end{array}$ & $\begin{array}{c}\text { Kadar Abu } \\
(\%)\end{array}$ & $\begin{array}{c}\text { Daya kembang } \\
(\%)\end{array}$ & $\begin{array}{c}\text { Kadar Total } \\
\text { Karoten }(\mathrm{mg} / 100 \mathrm{~g})\end{array}$ \\
\hline P0 & $13,81 \pm 0,92 \mathrm{c}$ & $1,83 \pm 0,11 \mathrm{a}$ & $136,38 \pm 0,4 \mathrm{a}$ & - \\
P1 & $14,01 \pm 0,12 \mathrm{c}$ & $1,75 \pm 0,3 \mathrm{a}$ & $130,75 \pm 0,77 \mathrm{~b}$ & $2,69 \pm 0,245 \mathrm{e}$ \\
P2 & $15,13 \pm 0,79 \mathrm{c}$ & $1,58 \pm 0,04 \mathrm{ab}$ & $129,55 \pm 0,59 \mathrm{c}$ & $9,23 \pm 0,53 \mathrm{~d}$ \\
P3 & $16,65 \pm 0,21 \mathrm{~b}$ & $1,37 \pm 0,36 \mathrm{abc}$ & $123,55 \pm 0,38 \mathrm{~d}$ & $13,01 \pm 0,65 \mathrm{c}$ \\
P4 & $17,73 \pm 0,94 \mathrm{ab}$ & $1,32 \pm 0,16 \mathrm{bc}$ & $111,49 \pm 0,37 \mathrm{e}$ & $21,38 \pm 0,46 \mathrm{~b}$ \\
P5 & $19,00 \pm 0,22 \mathrm{a}$ & $1,20 \pm 0,15 \mathrm{c}$ & $102,39 \pm 0,41 \mathrm{f}$ & $27,30 \pm 0,42 \mathrm{a}$ \\
\hline
\end{tabular}

Keterangan : Nilai rata - rata yang diikuti oleh huruf yang berbeda pada kolom yang sama menunjukkan perlakuan berbeda nyata $(\mathrm{P}<0,05)$

\section{Kadar Total Karoten}

Hasil sidik ragam menunjukkan bahwa perbandingan puree wortel dan terigu berpengaruh sangat nyata $(\mathrm{P}<0,01)$ terhadap total karoten roti tawar. Tabel 3 menunjukkan total karoten roti tawar dengan perbandingan puree wortel dan terigu berkisar antara 2,69\% sampai 27,30\%. Kadar total karoten teringgi diperoleh pada perlakuan P5 yaitu 27,30\%, sedangkan kadar total karoten terendah diperoleh pada perlakuan P1 yaitu 2,69\%. Peningkatan total karoten terjadi seiring dengan meningkatnya penambahan puree wortel, hal ini diperoleh dari data analisis bahan baku yang menunjukkan hasil kadar total karoten pada puree wortel lebih tinggi yaitu $12,30 \%$ dibanding dengan terigu yaitu $0 \%$.

\section{Sifat Sensoris}

Uji skoring dilakukan terhadap warna, aroma, tekstur, dan rasa. Hasil analisis uji hedonik terhadap warna, aroma, tekstur, rasa, keseragaman pori dan penerimaan keseluruhan dapat dilihat pada Tabel 4. Hasil analisis uji skoring terhadap warna, aroma, tekstur, dan rasa dapat dilihat pada Tabel 5.

\section{Warna}

Hasil sidik ragam menunjukkan bahwa perbandingan puree wortel dan terigu berpengaruh nyata $(\mathrm{P}<0,05)$ terhadap warna $(\mathrm{Uji}$ hedonik) roti tawar. Tabel 4 menunjukkan bahwa nilai rata-rata kesukaan panelis terhadap warna roti tawar berkisar antara 4,08 (biasa) sampai dengan 5,28( agak suka). Nilai rata-rata uji hedonik tertinggi terhadap warna roti tawar diperoleh pada perlakuan P4 yaitu 5,60 (suka), sedangkan nilai terendah diperoleh dari pelakuan P0 yaitu 4,08 (biasa). 
Tabel 4. Nilai rata - rata uji hedonik warna, aroma, tekstur, rasa dan keseragaman pori dan penerimaan keseluruhan roti tawar

\begin{tabular}{ccccccc}
\hline Perlakuan & Warna & Aroma & Tekstur & Rasa & Pori & $\begin{array}{c}\text { Penerimaan } \\
\text { keseluruhan }\end{array}$ \\
\hline P0 & $4,08 \mathrm{c}$ & $4,32 \mathrm{~d}$ & $5,56 \mathrm{a}$ & $5,84 \mathrm{a}$ & $5,76 \mathrm{a}$ & $5,64 \mathrm{a}$ \\
P1 & $4,76 \mathrm{~b}$ & $5,12 \mathrm{c}$ & $5,68 \mathrm{a}$ & $5,12 \mathrm{c}$ & $5,48 \mathrm{a}$ & $5,76 \mathrm{a}$ \\
P2 & $5,52 \mathrm{a}$ & $5,48 \mathrm{abc}$ & $5,72 \mathrm{a}$ & $5,40 \mathrm{bc}$ & $5,40 \mathrm{a}$ & $5,72 \mathrm{a}$ \\
P3 & $5,56 \mathrm{a}$ & $5,68 \mathrm{a}$ & $5,60 \mathrm{a}$ & $5,64 \mathrm{ab}$ & $5,44 \mathrm{a}$ & $5,88 \mathrm{a}$ \\
P4 & $5,60 \mathrm{a}$ & $5,52 \mathrm{ab}$ & $4,16 \mathrm{~b}$ & $5,32 \mathrm{bc}$ & $4,96 \mathrm{~b}$ & $5,52 \mathrm{a}$ \\
P5 & $5,28 \mathrm{a}$ & $5,16 \mathrm{bc}$ & $3,76 \mathrm{~b}$ & $5,40 \mathrm{bc}$ & $4,92 \mathrm{~b}$ & $4,68 \mathrm{~b}$ \\
\hline
\end{tabular}

Keterangan: Nilai rata - rata yang diikuti oleh huruf yang berbeda pada kolom yang sama menunjukkan perlakuan berbeda nyata $(\mathrm{P}<0,05)$

Tabel 5. Nilai rata - rata uji skoring warna, aroma, tekstur dan rasa roti tawar

\begin{tabular}{lrrrr}
\hline Perlakuan & Warna & Aroma & Tekstur & Rasa \\
\hline P0 & $1,04 \mathrm{f}$ & $1,64 \mathrm{e}$ & $5,72 \mathrm{a}$ & $1,60 \mathrm{~d}$ \\
P1 & $1,84 \mathrm{e}$ & $2,96 \mathrm{~d}$ & $5,56 \mathrm{a}$ & $2,96 \mathrm{c}$ \\
P2 & $2,88 \mathrm{~d}$ & $3,96 \mathrm{c}$ & $5,68 \mathrm{a}$ & $4,52 \mathrm{~b}$ \\
P3 & $3,64 \mathrm{c}$ & $4,96 \mathrm{~b}$ & $5,60 \mathrm{a}$ & $5,56 \mathrm{a}$ \\
P4 & $4,76 \mathrm{~b}$ & $5,60 \mathrm{a}$ & $4,76 \mathrm{~b}$ & $5,60 \mathrm{a}$ \\
P5 & $5,72 \mathrm{a}$ & $5,68 \mathrm{a}$ & $4,32 \mathrm{c}$ & $5,88 \mathrm{a}$ \\
\hline
\end{tabular}

Keterangan: Nilai rata - rata yang diikuti oleh huruf yang berbeda pada kolom yang sama menunjukkan perlakuan berbeda nyata $(\mathrm{P}<0,05)$

Hasil sidik ragam menunjukkan bahwa perbandingan puree wortel dan terigu berpengaruh nyata $(\mathrm{P}<0,01)$ terhadap warna (uji skoring) roti tawar. Tabel 5 menunjukkan bahwa nilai rata-rata terhadap warna roti tawar berkisar antara 1,04 (tidak orange) sampai dengan 5,72 (orange cerah). Nilai rata-rata uji skoring terhadap warna roti tawar tertinggi diperoleh pada perlakuan P5 yaitu 5,72 (orange cerah), sedangkan nilai terendah diperoleh pada pelakuan P0 yaitu 1,04 (tidak orange). Wortel memiliki kandungan karotenoid sebagai pigmen pemberi warna orange pada wortel. Tingkat warna orange pada roti tawar dipengaruhi oleh konsentrasi puree wortel, semakin tinggi konsentrasi puree wortel maka semakin orange warna yang dihasilkan.

\section{Aroma}

Hasil sidik ragam menunjukkan bahwa perbandingan puree wortel dan terigu berpengaruh nyata $(\mathrm{P}<0,05)$ terhadap aroma (uji hedonik) roti tawar. Tabel 4 menunjukkan bahwa nilai rata-rata kesukaan panelis terhadap aroma roti tawar berkisar antara 4,32 (biasa) sampai dengan 5,16 (suka). Nilai rata-rata uji hedonik tertinggi terhadap aroma roti tawar diperoleh pada perlakuan P3 yaitu 5,68 (suka), sedangkan nilai terendah diperoleh dari pelakuan P0 yaitu 4,32 (biasa).

Hasil sidik ragam menunjukkan bahwa perbandingan puree wortel dan terigu berpengaruh nyata $(\mathrm{P}<0,01)$ terhadap aroma (uji skoring) roti tawar. Tabel 5 menunjukkan bahwa nilai terhadap aroma roti tawar berkisar antara 1,64 (tidak khas wortel) sampai dengan 5,68 (khas 
wortel). Nilai rata-rata uji skoring tertinggi terhadap aroma roti tawar pada perlakuan P5 yaitu 5,68 (khas wortel), sedangkan nilai terendah diperoleh dari pelakuan P0 yaitu 1,64 (tidak khas wortel).

Menurut Rubatzky dan Yamguchi (1997) kantong minyak dalam ruang antarsel pada wortel mengandung minyak esensial yang menyebabkan aroma yang khas dari wortel. Dengan demikian, semakin tinggi penambahan puree wortel maka aroma roti tawar semakin kuat.

\section{Tekstur}

Hasil sidik ragam menunjukkan bahwa perbandingan puree wortel dan terigu berpengaruh nyata $(\mathrm{P}<0,05)$ terhadap tekstur (uji hedonik) roti tawar. Tabel 4 menunjukkan bahwa nilai rata-rata kesukaan panelis terhadap tekstur roti tawar berkisar antara 3,76 (biasa) sampai dengan 5,56 (suka). Nilai rata-rata uji hedonik tertinggi terhadap tekstur roti tawar pada perlakuan P2 yaitu 5,72 (suka), sedangkan nilai terendah diperoleh dari pelakuan P5 yaitu 3,76 (biasa).

Hasil sidik ragam menunjukkan bahwa perbandingan puree wortel dan terigu berpengaruh nyata $(\mathrm{P}<0,01)$ terhadap tekstur (uji skoring) roti tawar. Tabel 5 menunjukkan bahwa nilai rata-rata terhadap tekstur roti tawar berkisar antara 4,32 (biasa) sampai dengan 5,72 (empuk). Nilai rata-rata uji skoring tertinggi terhadap tekstur roti tawar dengan perbandingan puree wortel dan terigu diperoleh pada perlakuan P0 yaitu 5,72 (empuk), sedangkan nilai terendah diperoleh dari pelakuan P5 yaitu 4,32 (biasa).
Tekstur roti terbentuk karena adanya gluten yang berasal dari terigu. Gluten ini berasal dari protein terigu yang tidak larut dalam air tetapi mengikat air. Sifat fisik gluten yang elastis dan dapat mengembang ini memungkinkan adonan dapat menahan gas yang terbendtuk pada saat fermentasi. Keadaan ini memungkinkan produk mempunyai tekstur yang lembut dan elatis. Sementara puree wortel tidak mengandung gluten sehingga penambahan puree wortel akan menurunkan kemampuan dalam menahan gas yang akan menyebabkan tekstur roti tawar tidak empuk (Koswara, 2009).

\section{Rasa}

Hasil sidik ragam menunjukkan bahwa penambahan puree wortel berpengaruh nyata $(\mathrm{P}<0,05)$ terhadap rasa roti tawar. Tabel 4 Menunjukkan bahwa nilai rata-rata kesukaan panelis terhadap rasa roti tawar berkisar antara 5,12 (agak suka) sampai dengan 5,84 (suka). Nilai rata-rata uji hedonik terhadap tekstur tertinggi diperoleh pada perlakuan P0 yaitu 5,84 (suka), sedangkan nilai terendah diperoleh dari pelakuan P1 yaitu 5,12 (agak suka).

Hasil sidik ragam menunjukkan bahwa penambahan puree wortel berpengaruh nyata $(\mathrm{P}<0,01)$ terhadap rasa roti tawar puree wortel. Tabel 5 Menunjukkan bahwa nilai rata-rata terhadap rasa roti tawar puree wortel berkisar antara 1,6 (tidak khas wortel) sampai dengan 5,88 (khas wortel). Nilai rata-rata uji skoring terhadap rasa roti tawar tertinggi diperoleh dari perlakuan P5 yaitu 5,88 (khas wortel), sedangkan nilai terendah diperoleh dari pelakuan P0 yaitu 1,60 (sangat tidak khas wortel). Menurut Rubatzky 
dan Yamguchi (1997), rasa khas roti tawar puree wortel muncul disebabkan oleh minyak esensial yang terkandung dalam ruang parisikel wortel.

\section{Keseragaman Pori}

Hasil sidik ragam menunjukkan bahwa perbandingan puree wortel dan terigu berpengaruh nyata $\quad(\mathrm{P}<0,01) \quad$ terhadap keseragaman pori (uji hedonik) roti tawar. Tabel 4 menunjukkan bahwa nilai rata-rata kesukaan panelis terhadap keseragaman pori roti berkisar antara 4,92 (biasa) sampai dengan 5,76 (suka). Nilai rata-rata uji hedonik tertinggi terhadap keseragaman pori roti tawar diperoleh pada perlakuan P0 yaitu 5,64 (seragam), sedangkan nilai terendah diperoleh dari pelakuan P5 yaitu 5,68 (agak seragam). Tabel 4 menunjukkan bahwa semakin banyak penambahan puree wortel maka keseragaman roti tawar menjadi agak kurang seragam.

Meningkatnya ukuran pori-pori roti tawar berhubungan dengan jumlah gas yang diperangkap oleh gluten selama fermentasi. Konsentrasi terigu semakin banyak sehingga kandungan gluten dalam adonan meningkat akan menyebabkan ukuran pori-pori semakin baik dan seragam. Menurut Mudjisihono (1993), menyatakan bahwa gluten berfungsi menyetarakan keseragaman bentuk atau pori-pori terhadap roti tawar yang dihasilkan.

\section{Penerimaan Keseluruhan}

Hasil sidik ragam menunjukkan bahwa perbandingan roti tawar puree wortel dan terigu berpengaruh sangat nyata $(\mathrm{P}<0,01)$ terhadap penerimaan keseluruhan roti tawar puree wortel.
Tabel 4 menunjukkan bahwa nilai uji hedonik terhadap penerimaan keseluruhan roti tawar berkisar antara 4,68 (agak suka) sampai dengan 5,64 (suka). Penerimaan keseluruhan dipengaruhi oleh beberapa faktor seperti warna, aroma, tekstur, rasa dan keseragaman pori.

\section{KESIMPULAN DAN SARAN}

\section{Simpulan}

1. Perbandingan puree wortel dan terigu berpengaruh terhadap karakteristik kimia dan sifat sensoris roti tawar yang dihasilkan. Penambahan puree wortel yang semakin tinggi cenderung meningkatkan kandungan $\beta$ Karoten, kadar air dan kadar abu tetapi daya kembang yang dihasilkan semakin menurun.

2. Perbandingan puree wortel $30 \%$ : terigu $70 \%$ menghasilkan karakteristik roti tawar terbaik dengan kriteria kadar air 16,13\%, kadar abu $1,37 \%$, daya kembang $123,65 \%$ dan kadar total karoten 13,01 mg/100g. Sifat sensoris roti tawar yang dihasilkan yaitu warna oranye, aroma agak khas wortel, tekstur empuk, rasa khas wortel, keseragaman pori seragam dan penerimaan keseluruhan terhadap roti tawar sangat suka.

\section{Saran}

Berdasarkan hasil penelitian ini disarankan untuk menggunakan perbandingan 30\% puree wortel : $70 \%$ terigu pada proses pembuatan roti tawar dan dilakukan peneltian lanjutan mengenai daya simpan roti tawar dengan perbandingan puree wortel dan terigu. 


\section{DAFTAR PUSTAKA}

Anonimus. 1995.Syarat Mutu Roti Tawar. Dewan Standar Nasional. SNI 01-3840-1995. Jakarta.

Bima, B. 2014. Pengaruh Substitusi Mocaf (Modified Cassava Flour) Dan Penambahan Puree Wortel (Daucus Carota L) Terhadap Sifat Organoleptik Martabak Manis. Skripsi. Fakultas Teknik Tata Boga, Universitas Negeri Surabaya.

Gomez, K. A. Dan A. A. Gomez. 1995. Prosedur Statistik Untuk Penelitian Pertanian. UI Press, Jakarta.

Heruhidayat, A. W., 1998. Analisis Faktor-Faktor Yang Mempengaruhi Penerapan Manajeman Mutu Terpadu Pada Galih Bakery Ciledug, Tangerang, Banten,. Fakutas Sains Dan Teknologi. Universitas Islam Negeri Syarif Hidayatullah; Jakarta.

Koswara, S. 2009. Teknologi Pengolahan Telur (Teori dan Praktek). EBookPangan.com. diakses pada tanggal 22 Mei 2018.
Mulyani, T. U, Sarofa dan D. Irawati. 2013. Pembuatan roti manis dengan subtitusi wortel dan gluten. Jurnal Teknologi Pangan Vol 7 No (2). FTI UPN "Veteran; Jatim.

Rubatzk,V.E. dan M. Yamaguchi. 1997. Sayuran Dunia 2.Agromedia Pustaka; Jakarta.

Rukmana, R. 1995. Bertanam Wortel Kanisius. Yogyakarta.

Soekarto, S.T. 1985. Penelitian Organoleptik Untuk Industri Pangan dan Hasil Pertanian. Bhrata Krya Aksara; Jakrta.

Subagio, A. 2007. Manajemen Pengolahan Roti dan Kue. Graha Ilmu. Yogyakarta.

Sudarmadji, S. B, Haryono, dan Suhardi. 1997. Prosedur Analisa Untuk Bahan Makananan Dan Pertanian. Liberty; Yogyakarta.

Sudarno, 2015. Eksperimen Pembuatan Roti Tawar Substitusi Tepung Kulit Ari Kedelai. Universitas Indonesia, Jakarta.

Sutomo, B. 2006. Rahasia Membuat Roti Empuk Ala Bakery. Available from URL : http://www.Budiboga.com. Diakses pada tanggal 8 Mei 2018. 